AMELIA JEFFARES

\title{
SHOULD DEMENTIA SUFFERERS BE PUNISHED FOR PAST CRIMES?
}

\author{
LLM RESEARCH PAPER
}

LAWS 359: CONTEMPORARY ISSUES IN SENTENCING AND PENOLOGY

\section{FACULTY OF LAW}

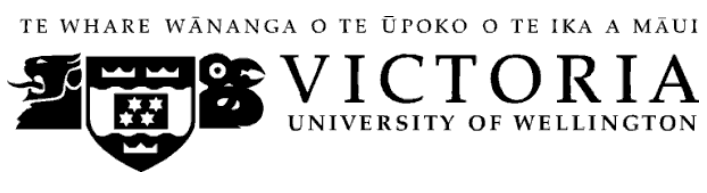

2014 


\section{CONTENTS}

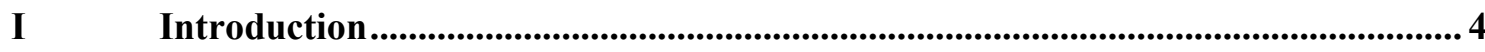

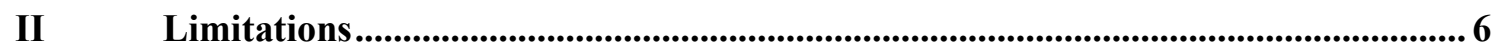

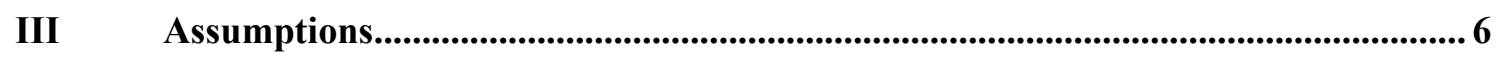

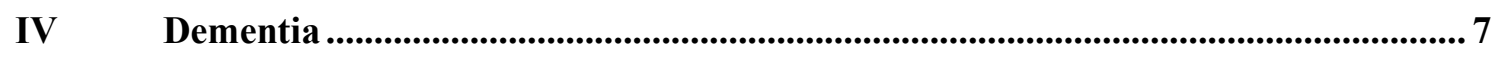

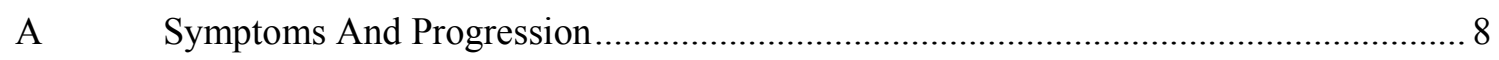

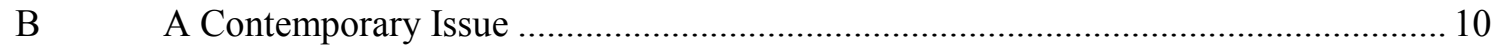

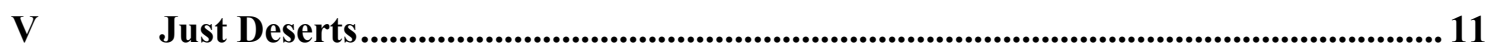

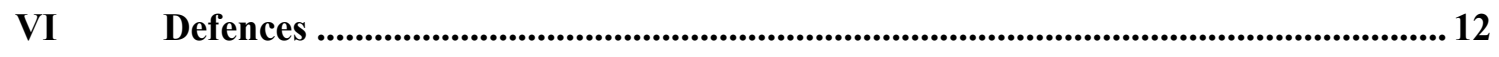

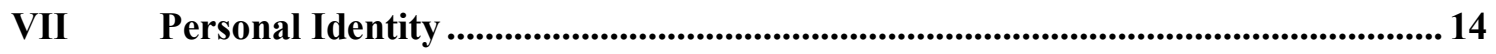

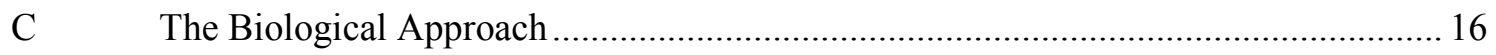

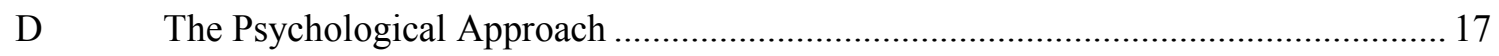

E The Psychological Approach And Advanced Dementia............................................ 18

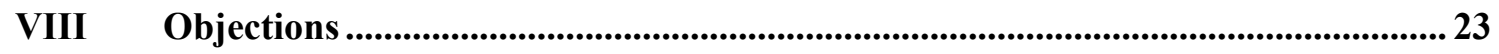

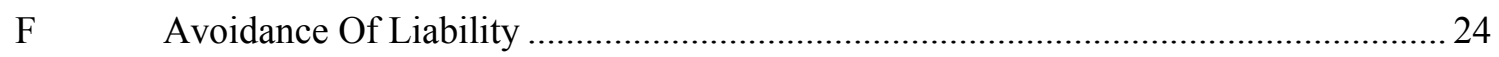

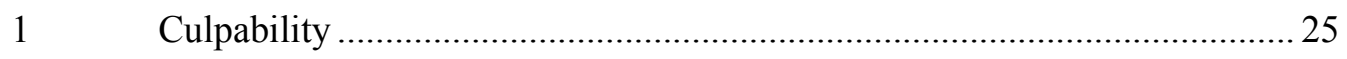

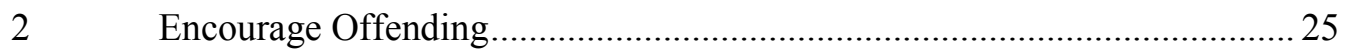

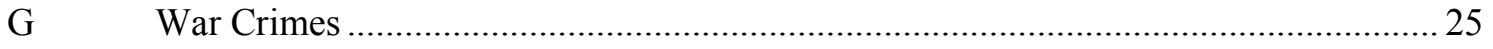

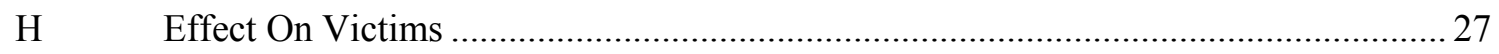

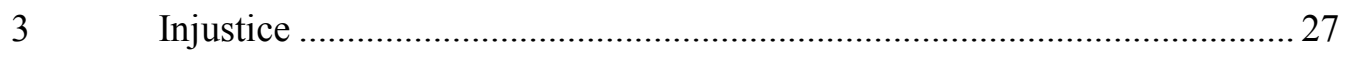

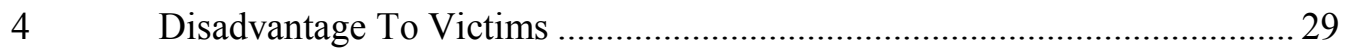

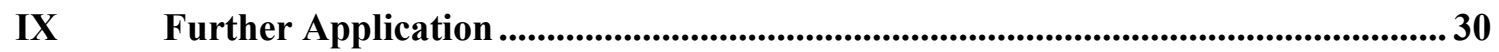

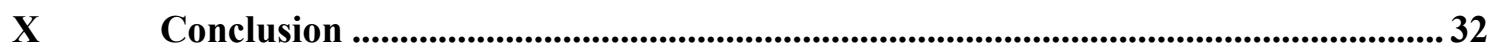




\title{
Abstract
}

This paper examines whether we ought to prosecute historic offences committed by people who have subsequently developed dementia. Currently, a person with dementia might avoid conviction on the basis of their currently diminished capacity. They may be unfit to plead, for example. The problem is that advanced dementia may undermine persistence of personal identity. Once someone develops dementia, they may no longer be the person who committed the crime. If so, they would not need to be excused for their offending. They would simply not be liable.

If we think persistence of personal identity is based on psychological factors - as most of us do - a person with advanced dementia will not be the same person as the one who committed the crime. They will not deserve prosecution, never mind punishment.

This issue has been overlooked by legal theorists. Although much has been written on the legal significance of dementia, it has been primarily in the context of advance directives or decision-making capacity. I will argue that advanced dementia is a challenge to criminal responsibility.

\section{Word length}

The text of this paper (excluding abstract, table of contents, footnotes and bibliography) comprises approximately 7,586 words.

\author{
Subjects and Topics \\ Criminal law \\ Culpability \\ Punishment \\ Personal identity \\ Dementia
}




\section{Introduction}

Suppose a person commits a crime at 25 years old. They are never caught for this crime. They regret what they did, but gradually, as time passes, the memory of it fades. At age 65, they begin to develop dementia. By age 70, the disease is in its late stages. They do not remember much of anything at all, never mind their crime, and their family laments how much they have changed. Evidence of the crime they once committed comes to light. They are charged. Does this person deserve to be punished?

This paper seeks to answer the question of whether we ought to prosecute historic offences committed by people who have subsequently developed dementia. The current capacities of such a person are not the focus of this paper. Rather, I approach this question with a philosophical approach to personal identity, within a just deserts framework.

Dementia (particularly in the form of Alzheimer's disease) has received plenty of academic attention. Primarily, as expected, this has been in the areas of health and gerontology. However, the legal and ethical significance of dementia has also been realised. Most legal writers have focused on a few issues, namely: the ethical responsibilities of health professionals to dementia-sufferers, decision-making by clients and the patient's ability to consent (whether to care, treatment or medical research). ${ }^{1}$ In the criminal justice arena, some authors have considered issues of fitness to stand trial.

In philosophy, the focus has mainly been on the status of advance directives for care. A number of writers in the personal identity debate have recognised the implications of dementia for our personal identity. ${ }^{2}$ The psychological effects of dementia seriously

${ }^{1}$ See for example: Various authors "Symposium: Joint Conference on Legal/Ethical Issues in the Progression of Dementia" (2001) 35 Georgia Law Review 451; Penney Lewis "Medical Treatment of Dementia Patients at the End of Life: Can the Law Accommodate the Personal Identity and Welfare Problems?" (2006) 13 European Journal of Health Law 219; Sjef Gevers "Dementia and the Law" (2006) 13 Eur J Health L 209.

2 Ronald Dworkin Life's Dominion: An argument about abortion, euthanasia, and individual freedom (Knopf Doubleday, New York, 1994); Allen Buchanan "Advance Directives and the Personal Identity 
threaten the persistence of identity through time. Few have recognised the significance of this to the criminal law, particularly to culpability for actions.

Alwynne Smart noticed the effect of personal identity on liability, and may have had dementia in mind, when he spoke of an offender who "we feel it would be unjust to punish ... because he was, in effect, not the same person that he was thirty years ago." 3 Antony Duff also touched on the issue: ${ }^{4}$

Could we instead argue that for reasons of logic, of utility or of justice the punishment for an offence must be imposed on the person who committed that offence; and that the necessary continuity of identity is between the offender and the person who is now to be executed is broken if insanity intervenes between offence and execution?

I draw on theories of personal identity to answer the opening question: does the personat-70 deserve punishment?

I proceed on the basis that one is morally responsible - and thus criminally responsible only for actions one performs. This will be explained in section III. I begin by describing the symptoms and psychological effects of dementia. I then, in section V, describe the rationale and relevance of just deserts. After introducing the main philosophical question - the persistence question - I describe the two main approaches to answering this question: the Psychological and the Biological approaches. I will argue that, if the Psychological Approach is correct, and persistence of personal identity rests on psychological factors, a person with advanced dementia will not be the same person as the one who committed the historical crime. They will not deserve to be punished.

In section VIII, I respond to three objections to this conclusion. Finally, I end by considering a possible extension of my argument. But first, it is necessary to state this paper's limitations and explain its assumptions.

Problem" (1988) 17 Philosophy \& Public Affairs 277; Rebecca Dresser "Dworkin on dementia: Elegant theory, questionable policy" (1995) 25 The Hastings Center Report 32; K Stern “Advance Directives" (1994) 2 Medical Law Review 57.

3 Alwynne Smart "Mercy" (1968) 43 Philosophy 345 at 345.

${ }^{4}$ Antony Duff Trials and Punishments (Cambridge University Press, Cambridge ; New York, 1986) at 19. 


\section{Limitations}

My discussion will be limited to serious offending. This allows me to set aside the issue of statutory limitation periods on prosecution. A person cannot be charged for simply any historical offending. Statutory limitation periods bar criminal proceedings with respect to some offences after a certain amount of time lapses. However, I will limit my discussion to crimes that do not have a limitation period..$^{5}$ These include, but are not limited to: murder, attempted murder, manslaughter, most sexual offending, most assaults and injuries to the person, bigamy, theft or conversion, robbery and blackmail, forgery, criminal damage and some offences under the Misuse of Drugs Act 1975.

\section{Assumptions}

My argument rests on some assumptions about the relationship between moral and criminal responsibility. These assumptions are well-supported in the philosophical literature on personal identity. ${ }^{6}$

The first is that one is morally responsible only for actions one performs. ${ }^{7}$ That is to say, "for someone now to be morally responsible for some past action $\varphi$, this person must be

${ }^{5}$ Under either the Criminal Procedure Act 2011 or the previous law. Section 405 of the Criminal Procedure Act states that "Despite s 25, if a charging document filed on or after the commencement date alleges the commission of an offence before the commencement date, the limitation period applicable to the filing of that charging document is that which would have applied under the law as it was before the commencement date."

6 By theorists including: Joseph Butler "Of Personal Identity" in John Perry (ed) Personal Identity (University of California Press, Berkeley, 1975); David DeGrazia Human Identity and Bioethics (Cambridge University Press, Cambridge, 2005); Walter Glannon "Moral Responsibility and Personal Identity” (1998) 35 American Philosophical Quarterly 231; John Locke “Of Identity and Diversity” in John Perry (ed) Personal identity (University of California Press, Berkeley, 1975) 33; Eric T Olson The Human Animal: Personal Identity Without Psychology (Oxford University Press, New York, 1997); Derek Parfit Reasons and persons (Clarendon Press, Oxford, 1984); Thomas Reid “Of Mr Locke's Account of Our Personal Identity" in John Perry (ed) Personal identity (University of California Press, Berkeley, 1975) 113. 
the same person as the agent of $\varphi .^{\prime 8}$ One might object that we sometimes hold people responsible for others' actions; for example, we might blame a parent when his child runs off in a shop and breaks something. However, we really consider the parent responsible not for the child's action - breaking the item - but for their own action - their failure to keep control of their child, for example.

Second, moral responsibility is necessary for criminal responsibility. There are obvious objections to this claim, such as the existence of strict liability. However, as discussed above, my discussion will be limited to serious, 'truly criminal' offending. There is a wellestablished presumption that: ${ }^{9}$

Where the offence is truly criminal the Crown must establish a mental element, namely, that the accused who committed the prohibited act did so intentionally or recklessly, with knowledge of the facts constituting the offence, or with wilful blindness toward them; and mere negligence is excluded from the concept of the mental element required for conviction.

From these assumptions, the third deductively follows. As criminal responsibility entails moral responsibility, for someone now to be criminally responsible for some past action $\varphi$, this person must be the same person as the agent of $\varphi$.

\section{Dementia}

Dementia describes a category of brain diseases that severely inhibit a person's thinking and functioning. ${ }^{10}$. It is important to note that, while dementia is often associated with older people, it is not a normal part of ageing. ${ }^{11}$ It is a degenerative disease with serious psychological and physical effects.

\footnotetext{
${ }^{7}$ Or omissions.

${ }^{8}$ David Shoemaker "Responsibility without identity" (2012) 185 Science 1124 at 109.

${ }^{9}$ Civil Aviation Department v MacKenzie [1983] NZLR 78 at 44; see also Millar v Ministry of Transport [1986] 1 NZLR 660; B (A Minor) v Director of Public Prosecutions [2000] 2 WLR 452 (HL).

${ }^{10}$ Alzheimer's Disease International World Alzheimer Report 2009 (2009).

11 World Health Organization and Alzheimer's Disease International Dementia: A Public Health Priority (World Health Organization; Alzheimer's Disease International, Geneva; London, 2012) at 2.
} 
There are many sub-types, but I will limit my discussion to dementia caused by Alzheimer's disease (Alzheimer's-dementia). ${ }^{12}$ It is the most common sub-type; accounting for between 60 and 80 per cent of dementia cases.

\section{A Symptoms and Progression}

Typically, the onset of Alzheimer's is at around 65 years old. Although it can set in later, symptoms rarely appear earlier. ${ }^{13}$ Once symptoms appear, the disease progresses over five to ten years in stages. ${ }^{14}$ Although medications can alleviate some of the physical symptoms, there is no cure for dementia.

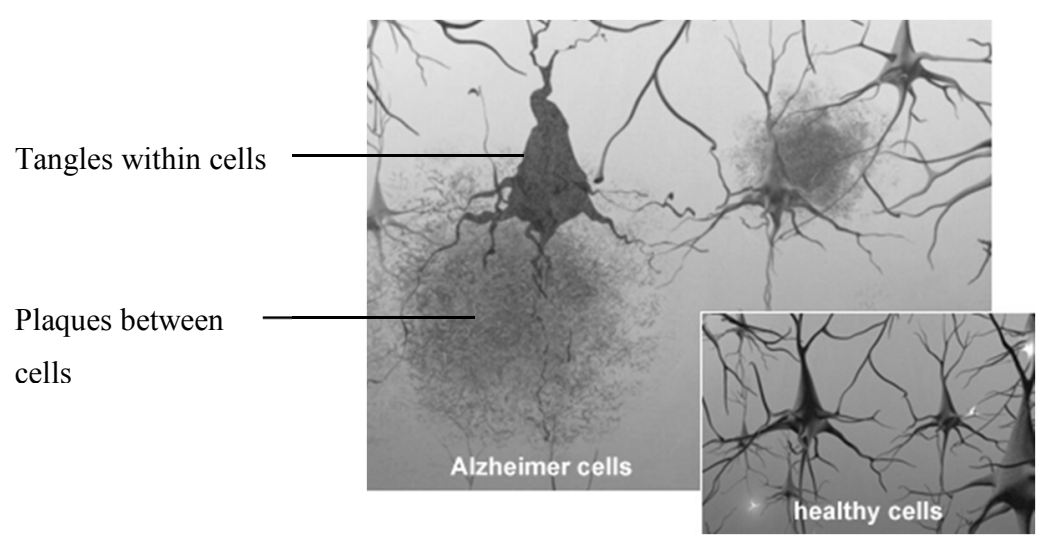

Figure $1^{15}$

Changes begin to occur in the brain even before the first symptoms appear. These are primarily in the form of plaques and tangles (see figure 1). Plaques are abnormal deposits of a protein between nerve cells which block synapses and trigger cell deterioration.

\footnotetext{
12 Although I am limiting my discussion to Alzheimer's-dementia, my argument could also apply to other kinds of non-reversible dementia, including vascular dementia, dementia with Lewy bodies and frontotemporal dementia (especially the behavioural variant).

${ }^{13}$ World Health Organization and Alzheimer's Disease International, above n 11, at 8.

14 At 90.

15 Alzheimer's Association “Alzheimer's Disease and the Brain: Under the microscope" (2011) Alzheimer's Association <www.alz.org $>$.
} 
Tangles are twisted strands of protein which prevent nutrients from reaching brain cells, causing their death. ${ }^{16}$

In the first year or two, as neurons start to work less efficiently, one can observe mild cognitive decline. ${ }^{17}$ The most prominent symptom is usually short-term memory loss. The sufferer may also have difficulty performing common tasks. ${ }^{18}$

At the second stage - moderate cognitive decline - plaques and tangles form in other areas of the brain, including the hippocampus, which is responsible for memory. ${ }^{19} \mathrm{AD}$ sufferers may forget their own history. They may not remember where they grew up or what school they attended. They may experience behavioural changes, like losing interest in their former hobbies and becoming moody or withdrawn. It is common to exercise poor judgement and make poor decisions. ${ }^{20}$

As the damage progresses, "affected regions begin to shrink in a process called brain atrophy." 21 Sufferers may be unable to recall their address and home town and may entirely forget recent experiences. They may forget their family, their own name and be unable to recognise themselves in a mirror. They may become confused about time or their surroundings. There can be major personality and behavioural changes and aggressive behaviour is common. ${ }^{22}$

\footnotetext{
${ }^{16}$ National Institute on Aging Alzheimer's Disease: Unraveling the Mystery (08-3782, 2008) at 21.

${ }^{17}$ At all stages there are physiological symptoms, but I am focusing on the psychological effects as they are the most relevant to my argument.

18 Alzheimers New Zealand "Progression of dementia" Alzheimers New Zealand $<$ www.alzheimers.org.nz $>$.

${ }^{19}$ National Institute on Aging, above n 16, at 27.

${ }^{20}$ World Health Organization and Alzheimer's Disease International, above n 11, at 90.

${ }^{21}$ National Institute on Aging, above n 16, at 26.

22 Alzheimer's Association "7 Stages of Alzheimer's \& Symptoms" Alzheimer's Association $<$ www.alz.org $>$.
} 
The last stage is very severe cognitive decline. By this stage, "damage is widespread, and brain tissue has shrunk significantly" (see figure 2). ${ }^{23}$ Sufferers may completely lose the ability to respond to their environment. They may say nonsense words or phrases. At this stage, the physical symptoms will usually be so severe that they will require constant supervision in a special facility. ${ }^{24}$

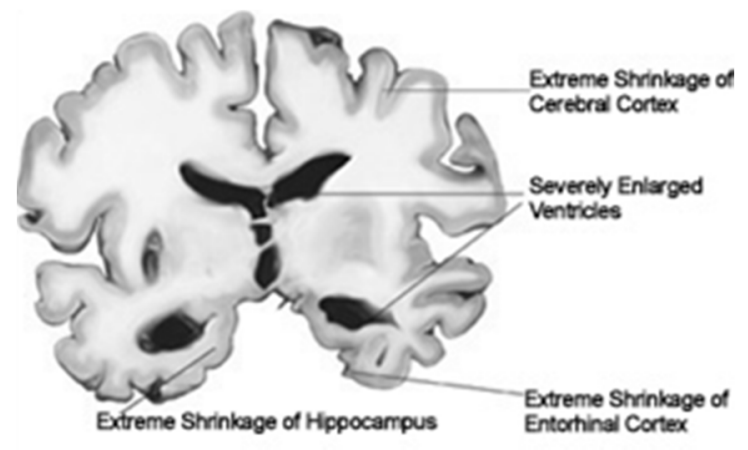

Figure $2^{25}$

\section{B A Contemporary Issue}

This issue - the prosecution of historic offences committed by people who have subsequently developed dementia - is admittedly not an especially pertinent one in present-day New Zealand. There have been very few cases with these facts. ${ }^{26}$ Nevertheless, it is an important topic to consider as it is likely to be a growing concern.

The population of New Zealand is ageing. As of June 2014, there were approximately 650,400 New Zealanders aged 65 and over, comprising just over 14 per cent of the

\footnotetext{
${ }^{23}$ National Institute on Aging, above n 16, at 26.

${ }^{24}$ Alzheimers New Zealand, above n 18.

${ }^{25}$ National Institute on Aging, above n 16, at 32.

${ }^{26}$ I was only able to locate two cases of historic offending by an offender who developed dementia by the time of the trial: $R v$ Shoebridge HC Hamilton T014189, 12 September 2002; and $R v$ Milligan [2013] NZHC 118. In two other cases it was difficult to determine whether the offending was sufficiently historic: ; $R$ v Hart CA199/93, 17 November 1993; $R$ v TA HC Auckland T296/96, 12 December 1996 Personal identity issues were not discussed in any of these cases.
} 
population. ${ }^{27}$ This is expected to increase to 1.37 million by 2051 (23 per cent of the population). ${ }^{28}$

Relatedly, the number of people with dementia in New Zealand is also increasing. In New Zealand, the incidence of dementia rose 18 per cent from 2008 to 2011, and it is expected to keep increasing rapidly as our population ages. It is predicted that by 2050 there will be over 40,000 new cases each year and the total number of New Zealanders with dementia will have tripled to 147,359. ${ }^{29}$ Further, the World Alzheimer Report 2011 showed that in countries like New Zealand, only around 60 per cent of cases are diagnosed and documented. ${ }^{30}$ The actual incidence could be much higher. Thus, the issues identified in this paper will only be magnified as the incidence of dementia rises.

\section{Just Deserts}

Under the theory of just deserts, the focus is on what punishment an offender deserves for the particular offence they have committed. We can only justify punishing the guilty, and they must be treated as rational agents. Just deserts has two elements: retribution and denunciation. Denunciation justifies punishment on the basis that it symbolises society's condemnation of the criminal act. Retribution is about punishing an offender because they deserve it. The particular conception of retribution is not important for our purposes. All conceptions require the offender to be blameworthy for punishment to be inflicted. As I will argue that the offender is not blameworthy, punishment will not be justified under just deserts.

\footnotetext{
${ }^{27}$ Geoff Bascand (Government Statistician) "National Population Projections: 2011(base)-2061" (19 July 2012) Statistics New Zealand <www.stats.govt.nz $>$.

${ }^{28}$ Statistics New Zealand "Projected population of New Zealand by age and sex, 2011(base)-2061" (22 October 2013) NZStat $<$ nzdotstat.stats.govt.nz $>$.

${ }^{29}$ Deloitte Access Economics Updated Dementia Economic Impact Report, 2011, New Zealand (2012).

${ }^{30}$ Alzheimer's Disease International World Alzheimer Report 2011 (Alzheimer's Disease International, London, 2011) at 16.
} 
There are three reasons why I focus on the just deserts theory of punishment. First, it is based on culpability at the time of offending, rather than current consequentialist justifications. Out of all the popular theories of punishment, it makes the most sense to consider in the context of personal identity and culpability. Second, while some theories of punishment require empirical evidence to prove their validity (i.e. rehabilitation, deterrence, incapacitation), this is not necessary for a discussion of just deserts. Finally, although there is no explicit primary rationale for sentencing in $\mathrm{s} 7$ of the Sentencing Act, it seems that s 8 - particularly ss (a), (b), and (e) - leads judges toward just deserts.

\section{Defences}

In general, there are three basic reasons that we might think a person ought not to be punished. A simple example will illustrate them:

A takes his 4 year old son, B, to a football game. They see a fight break out in the stands. A police officer, C, forcibly arrests one of the people involved in the fight. B, copying something he saw in the fight, stomps on A's toe, breaking it. Should A, B or $\mathrm{C}$ be punished under the criminal law?

We general think that none of them ought to be punished, but different reasons apply to each. These reasons correspond with the three types of criminal defences: denial, justification and excuse. ${ }^{31}$ We think that $\mathrm{C}$ should not be punished as she was justified in exercising her lawful duty. B should not be legally punished either; he is excused due to his young age. ${ }^{32}$ A definitely should not be punished; he can deny that he did anything.

Clearly the person with dementia is not like $\mathrm{C}$; she was not justified when she committed the crime 55 years ago. The most intuitive reason not to punish her or others like her is

31 For detailed discussion on the types of defences, see: JL Austin "A Plea for Excuses" (1956) 57 Proceedings of the Aristotlean Society 1; Douglas Husak "On the Supposed Priority of Justification to Excuse" [2005] 24 Law and Philosophy 557; Kimberly Kessler Ferzan "Justification and Excuse" in John Deigh and David Dolinko (eds) The Oxford Handbook of the Philosophy of the Criminal Law (Oxford University Press, 2011); John Gardner “The Mark of Responsibility” (2003) 23 Oxford Journal of Legal Studies 157.

${ }^{32}$ His parent may wish to punish him (to discourage future misbehaviour, for example), but I am only concerned with punishments imposed by the State. 
that we think she is like B; we want to excuse her due to her present incapacities. We might think she should claim unfitness to plead or invoke an insanity defence. This seems appropriate when we consider HLA Hart's description of an excuse: ${ }^{33}$

When someone is excused because he offended unintentionally, the underlying moral conception is not that this action is of a kind which it is the policy of the law to permit or even welcome; it is that when we investigate the mental condition of the particular offender, we find that he lacked the normal capacity to conform to the law's requirements.

However, I will examine whether the real reason we ought not to punish her is that she has the third kind of defence, like A; she can deny agency. I will argue that this is what the Psychological Approach to personal identity implies.

One might object that it does not matter how we conceptualise her defence. After all, however we cash it out, she will not be liable. However, it is unsatisfactory to say someone is excused when they actually have not committed a crime.

Many theorists believe that the three kinds of defence mentioned above lie along a spectrum. ${ }^{34}$ Douglas Husak calls this the "serial view of defenses". ${ }^{35}$ According to this view, it is only necessary to consider each type of defence if the preceding types are unavailable, and alleging a given defence "should be understood to concede the unavailability of each defense prior to it along the spectrum." 36

Although there is some disagreement about the ordering of justifications and excuses, most theorists seem to agree that a denial, such as a denial that the offence was

\footnotetext{
${ }^{33}$ HLA Hart The Concept of Law (Third edition ed, Oxford University Press, Oxford, United Kingdom, 2012) at $174-5$.

${ }^{34}$ For example: George Fletcher Rethinking Criminal Law (Little, Brown and Company, Boston, 1978) at 309; Paul Robinson Criminal Law Defenses (West Publishing, St Paul, 1984) at 105; Jerome Hall "Comment on Justification and Excuse" (1976) 24 American Journal of Comparative Law 638 at 640.

${ }^{35}$ Douglas N Husak Philosophy of Criminal Law (Rowman \& Littlefield, Totowa, 1987) at 194.

${ }^{36}$ At 194.
} 
committed by the accused, is "the first and simplest kind of defense". ${ }^{37}$ Whether or not we accept the serial view of defences on a theoretical level, the precedence of defences of denial to justification to excuse - seems to align with our intuitions and popular opinions. For example, if we hear that someone acted in self-defence (a typical justification), we assume that they did commit the act that constituted a crime; that is, they could not argue a denial. If we find out someone was excused due to insanity, we assume that they could not only committed the act, but that they did not act in selfdefence.

This is why it is important to correctly classify the kind of defence the person with AD is relying on. Such a person ought not to argue an excuse if they have a better kind of defence - a denial - available.

\section{Personal Identity}

Personal identity is an important topic in philosophy. It raises many questions, for example: What makes me $m e$ ? What is a person? Is a foetus a person? Can a non-human animal, like a chimp, be a person? The answers to all these questions have implications for the law.

However, we are interested in a different question. We are assuming (see part II) that we are justified in holding $\mathrm{X}$ responsible for a past action only if $\mathrm{X}$ is identical to the person who performed that action. That means our relevant question is about persistence of identity. This does not address the criteria for personhood or personal identity, it is purely

${ }^{37}$ At 189. 
concerned with what it means for personal identity to persist, or not, through time. ${ }^{38}$ That is: under what circumstances is $\mathrm{X}$ at $\mathrm{t}_{1}$ identical to $\mathrm{Y}$ at some other time? ${ }^{39}$

In philosophy, there are two main approaches to answering this question: the Psychological Approach (PA) and the Biological (or somatic) Approach (BA). ${ }^{40}$ I will focus on the Psychological Approach, which is "[b]y far the most popular view of personal identity." ${ }^{41}$ It is a complex theory, but, at its core, it asserts that our identity over time has something to do with our psychology. ${ }^{42}$ Accordingly, significant psychological changes, such as those that occur with dementia, can undermine identity (and thus desert of punishment). ${ }^{43}$ This means I can examine the effects of dementia and compare them to the requirements of the Psychological Approach. I will examine whether a person with late-stage dementia can be considered sufficiently disconnected from the person who committed the crime to justify reduced or no punishment. However, first I will briefly describe the Biological Approach and some of its problems, in order to show how the Psychological Approach can succeed where it fails.

$\overline{38}$ I will show that a person with $\mathrm{AD}$ is not the same person who committed the crime, which leaves two options open: the person with $\mathrm{AD}$ is a different person or they are not a person at all. I do not need to address whether a person with $\mathrm{AD}$ is a person, in the philosophical sense. They will not be accountable for the crime, whether they qualify for personhood or not.

39 The broadest version of the persistence question is "Under what possible circumstances is a person who exists at one time identical with something that exists at another time (whether or not it is a person then)?": Eric T Olson "Personal Identity" in Edward N Zalta (ed) The Stanford Encyclopedia of Philosophy (Winter $2010 \mathrm{ed}, 2010)$.

${ }^{40}$ I will not discuss other views, such as the narrative approach or four-dimensionalism, in this essay. However, it seems that on the narrative approach, too, dementia can undercut persistence of personal identity through time. For example, see DeGrazia, above n 6.

41 David Shoemaker "Personal Identity and Ethics" in Edward N Zalta (ed) Stanford Encyclopedia of Philosophy (Spring 2014 ed, 2014).

42 As opposed to our physical body.

${ }^{43}$ For example, see Parfit, above n 6. 


\section{The Biological Approach}

The Biological Approach holds that a person, $\mathrm{X}$, at $\mathrm{t}_{1}$ is the same individual as $\mathrm{Y}$ at some other time if and only if $\mathrm{X}$ is biologically continuous with $\mathrm{Y} .{ }^{44}$ This means that $\mathrm{X}$ and $\mathrm{Y}$ are the same human animal, or share the same body. On this view, an action is X's if it was performed by "an individual human organism with whom one is now biologically continuous." 45

The Biological Approach succeeds in explaining our intuitions about identity in some thought experiments. For example, consider a case presented by David Shoemaker, called Drunken Mel: 46

...suppose Mel has gotten very drunk and then, when pulled over by the cops, goes on an anti-Semitic tirade against the arresting officer. When he wakes up in jail the next morning, Mel truly does not remember a thing.

Most people think that the tirade the night before is attributable to Mel for the purposes of moral assessment. The BA also determines that Mel is responsible. That is because Mel is the same human organism as the one who performed the drunken tirade.

However, this approach fails to provide the right answer in some other important examples. These examples, based on thought experiments by Shoemaker, show that biological continuity is neither necessary nor sufficient to ground personal identity over time.

First, imagine that I go on a killing spree. ${ }^{47}$ I kill my first victim. For reasons known only to me, I decide to drug an unsuspecting bystander and swap the contents of my brain with

\footnotetext{
${ }^{44}$ Support for this approach can be found in: William R Carter "How to Change Your Mind" (1989) 19 Canadian Journal of Philosophy 1; David Mackie "Personal Identity and Dead People" (1999) 95 Philosophical Studies 219; Olson, above n 6; Peter Van Inwagen Material beings (Cornell University Press, Ithaca, NY, 1990); and Bernard Williams "The Self and the Future" in John Perry (ed) Personal Identity (University of California Press, Berkeley, 1975).

${ }^{45}$ Shoemaker, above $\mathrm{n} 8$, at 112.

${ }^{46}$ At 112.

${ }^{47}$ Adapted from "Cerebrum Transfer": At 112-113.
} 
her. The person who wakes up is exactly like me psychologically. She remembers killing my first victim, shares my criminal values and has inherited my intention to kill again. Most of us think we could attribute my first killing to her. However, on the Biological Approach, we cannot. Remember, on this view, an action is hers only if it was performed by an individual human organism with whom she is now biologically continuous. She is not the same human organism as the one who committed the killing, so the action is not hers. This example shows biological continuity is not necessary.

It is also not sufficient. Suppose I abruptly enter a fugue stage lasting two years, during which time I am called 'Clementine'. ${ }^{48}$ Clementine is very different from me psychologically, and she drifts around committing minor offences. After two years, I suddenly come to, with no idea where I am or what I have done. I never remember what happened during the missing time, even when I am shown photos and newspaper articles. We do not think I should be held responsible for Clementine's actions. But I am biologically continuous with her, so on the Biological Approach, her actions are mine.

\section{The Psychological Approach}

The Psychological Approach states that a person, $\mathrm{X}$, at $\mathrm{t}_{1}$ is the same individual as $\mathrm{Y}$ at some other time if and only if $\mathrm{Y}$ is uniquely psychologically continuous with $\mathrm{X} \cdot{ }^{49}$ Psychological continuity means that there is a chain of overlapping direct psychological connections between the mental states of $\mathrm{X}$ and $\mathrm{Y} .{ }^{50}$ Theorists differ on what kind of connections this may consist of, but they usually include ones like memories, intentions, beliefs, desires, goals and character traits. The connections between mental states should

\footnotetext{
${ }^{48}$ Adapted from "Sudden Fugue": At 113.

49 This view has been endorsed in: David K Lewis "Survival and Identity" in Raymond Martin and John Barresi (eds) Personal Identity (Blackwell Publishing, Malden, 2003); Thomas Nagel "Brain Bisection and the Unity of Consciousness" in John Perry (ed) Personal identity (University of California Press, Berkeley, 1975); Robert Nozick Philosophical Explanations (Clarendon Press, Oxford, 1981); Derek Parfit "Personal Identity" in John Perry (ed) Personal Identity (University of California Press, Berkeley, 1975); Parfit, above n 6; and John Perry "Can the Self Divide?" (1972) 69 The Journal of Philosophy 463. Locke's criterion is also a kind of psychological approach; see Locke, above n 6.

${ }^{50}$ Shoemaker, above $\mathrm{n} 8$, at 113 .
} 
not be coincidental; they should be made in particular ways. For example, on David Lewis's view, they should be both similar and causally dependent: "there should not be too much change overall...[and] each succeeding mental state causally depends for its character on the states immediately before it." ${ }^{51}$

Under this view, an action is $\mathrm{X}^{\prime} \mathrm{s}$ if it was performed by someone with whom $\mathrm{X}$ is now uniquely psychologically continuous.

The Psychological Approach is able to account for the cases above. After I swap the contents of my brain, we can attribute my killing to the person who wakes up. She will share sufficient overlapping psychological connections with me to establish ownership of the actions. This is the intuitive result; as Eric Olson has said, "It seems obvious that you would go along with your brain if it was transplanted, and that this is so because that organ would carry with it your memories and other mental features." 52 And in the second case, I do not need to worry about being held responsible for Clementine's actions. There is no psychological continuity between us - we do not share memories, intentions, beliefs, desires, goals or character traits - so her actions are not mine.

The PA is the approach most people find the most plausible, probably because they share David Lewis's view that "when I consider various cases in between commonplace survival and commonplace death, I find that what I mostly want in wanting survival is that my mental life should flow on." ${ }^{13}$ I will proceed on the basis that the Psychological Approach provides the correct account of personal identity.

\section{E The Psychological Approach and Advanced Dementia}

Let us consider whether we can justify punishing a person with $\mathrm{AD}$ under the Psychological Approach by returning to the opening scenario:

\footnotetext{
${ }^{51}$ Lewis, above n 49, at 144.

${ }^{52}$ Olson, above n 39.

${ }^{53}$ Lewis, above n 49, at 144.
} 
Suppose a person commits a crime at 25 years old. They are never caught for this crime. They regret what they did, but gradually, as time passes, the memory of it fades. At age 65, they begin to develop dementia. By age 70, the disease is in its late stages. They do not remember much of anything at all, never mind their crime, and their family laments how much they have changed. Evidence of the crime they once committed comes to light. They are charged. Does this person deserve to be punished?

Remember the assumption that for someone now to be criminally responsible for some past action $\varphi$, this person must be the same person as the agent of $\varphi .{ }^{54}$ According to the PA, the person-at-70 will be the same person as the agent of the crime, person-at-25, if and only if person-at-70 is uniquely psychologically continuous with person-at- 25 . We must ask whether there is an overlapping chain of direct psychological connections such as memories, intentions, beliefs, desires, goals and character traits - between person-at-70 and person-at-25.

It seems clear that there are not. Given what we have said about the PA, this is intuitively compelling. Indeed, philosophers in various fields have come to this conclusion. For example, Jeff McMahan (writing on personal identity) has said: ${ }^{55}$

We know what will happen as the disease progresses: assuming that the person's body remains alive, his mental capacities, including memory, will gradually deteriorate until his brain will cease to be capable of even the most rudimentary forms of thought or perception. By that point, the person will clearly have ceased to exist, according to the Psychological Account, for the patient with advanced Alzheimer's will clearly not be psychologically continuous with the person in the early stages of the disease.

Others, writing on advanced directives, call this the "Someone Else Problem." They recognise that, when someone gets advanced dementia, "the person who wrote the advance directive is not the individual to whom it would apply." 56

However, there is more compelling evidence. Let us consider some of the kinds of psychological states - memory, intentions and character traits - in turn. I will show how

\footnotetext{
${ }^{54}$ See Part II.

55 Jeff McMahan The Ethics of Killing (Oxford University Press, 2002) at 43-44.

${ }^{56}$ DeGrazia, above n 6, at 165; See also, for example: Martin Harvey “Advance Directives and the Severely Demented" (2006) 31 Journal of Medicine and Philosophy 47; Dresser, above n 2; Buchanan, above n 2.
} 
continuity of these states is undermined by advanced dementia, with reference to physiological brain changes and observable behavioural changes. Finally, I will use a concrete example to illustrate disruption of personal identity.

First, consider memory. As stated, memory loss is one of the earliest symptoms of Alzheimer's-dementia. In fact, the Diagnostic and Statistical Manual of Mental Disorders (DSM) requires "Clear evidence of decline in memory and learning" for a diagnosis. ${ }^{57}$ PET scans (a neuro-imaging technique) have revealed that glucose metabolism - which is associated with "decreased cognitive function", especially in memory and language decreases as dementia advances. ${ }^{58}$

Memory impairment worsens as plaques and tangles spread to the brain's hippocampus, until "In advanced stages of dementia, memory impairment is so severe that the person forgets his or her occupation, schooling, birthday, family members, and sometimes even name." 59

Second, intentions fulfilled in action. These are obviously significantly altered by AD. Plaques and tangles form early in areas related to thinking and planning. This leads to disturbances in executive functioning, which "involves the ability to think abstractly and to plan, initiate, sequence, monitor and stop complex behaviour."60 Poor judgement is also common.

Finally, consider character traits. According to the DSM, AD sufferers can "show disinhibited behaviour, including making inappropriate jokes, neglecting personal hygiene, exhibiting undue familiarity with strangers, or disregarding conventional rules

\footnotetext{
57 American Psychiatric Association Diagnostic and statistical manual of mental disorders (5th ed, American Psychiatric Association, Washington, DC, 2013) at "Neurocognitive Disorders".

${ }^{58}$ Susan Landau and others, Alzheimer's Disease Neuroimaging Initiative "Associations between cognitive, functional, and FDG-PET measures of decline in AD and MCI" (2011) 32 Neurobiology of Aging 1207.

59 American Psychiatric Association Diagnostic and statistical manual of mental disorders (4th text revision ed, American Psychiatric Association, Washington, DC, 2000) at 148.

${ }^{60}$ At 149 .
} 
of social conduct." ${ }^{61}$ Character changes can be very difficult for family and friends of people with AD. One carer said: "I look at her, think she is a stranger, complete stranger." ${ }^{62}$ According to another: "it is like bereavement, I think it is a bereavement. For that person that was there and is no longer there anymore and you get an entirely different person." 63 Character traits, like memories and intentions, are not connected to earlier states in the right way to ground personal identity. In dementia: ${ }^{64}$

...the new personality is the product of the illness rather than of any self-creative process. It does not reflect the choices or values of the person before the onset...

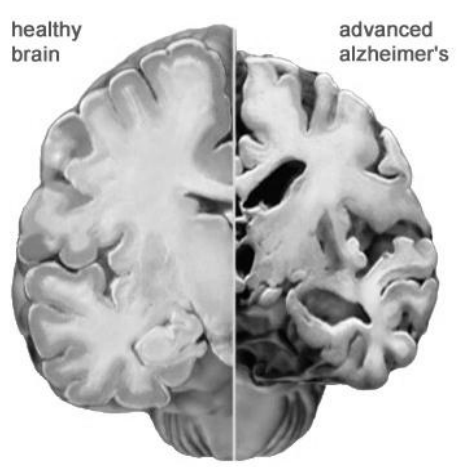

Figure $3^{65}$

Overall, the damage to the brain is extensive. Neurons are damaged. Synapses, which carry signals between neurons, are impaired.

Over time, our experiences create patterns in signal type and strength. These patterns of activity explain how, at the cellular level, our brains code our thoughts, memeories, skills and sense of who we are.

According to the Alzheimer's Association, these patterns "change when Alzheimer's disease of a related disorder disrupts nerve cells and their connections to one another."

\footnotetext{
${ }^{61}$ American Psychiatric Association, above n 59.

${ }^{62}$ Susan M Benbow and Paul Kingston “"Talking about my experiences ... at times disturbing yet positive': Producing narratives with people living with dementia" [2014] Dementia 1 at 7.

${ }^{63}$ At 7.

64 Jonathan Glover Alien Landscapes?: Interpreting Disordered Minds (Harvard University Press, Cambridge, Massachusetts, 2014) at 375.
}

${ }^{65}$ Alzheimer's Association, above n 15. 
Figure 3, above, shows how the entire cortex shrivels in AD. This eventually affects "nearly all" the brain's functions. It is difficult to recognise any psychological continuity with the person's former self.

The lack of psychological continuity is borne out in accounts by those with first-hand experience of $\mathrm{AD}$. As painful as it may be, many acknowledge that the person with $\mathrm{AD}$ is not the person they once knew. For example, journalist Michael Wolff wrote: ${ }^{66}$

I hesitate to give my mother a personality here. It is the argument I have with myself everyday - she is not who she was; do not force her to endure because of what she once was. Do not sentimentalize.

An especially illuminating account was written by John Bayley, the husband of the author Iris Murdoch. Murdoch was a novelist and philosopher. She had been the celebrated author of 26 novels, as well as poetry and plays. She was a Booker Prize winner and a Dame of the British Empire. In her 70s, she was diagnosed with Alzheimer's disease. Bayley's description clearly shows that she has lost not only her memories, but her beliefs, goals and desires.

First, her memories wane. She forgets who the Prime Minister is and what words mean. Gradually, she begins to forget event, not only from her past but from earlier that day. For example, Bayley describes what happens after attending a party: "When we get home I try to keep Iris interested in the party...But it is not remembered. Iris begins to say anxiously, 'When do we go?"'67

Her goals and desires no longer seem connected. Bayley says Iris no longer distinguishes between what she desires to do, and simply what is happening. He thinks her whole inner world has gone. He says: ${ }^{68}$

Her tears sometimes seem to signify a whole inner world which Iris is determined to keep from me and shield me from. There is something ghastly in the feeling of relief that this can't be so...

\footnotetext{
${ }^{66}$ Michael Wolff “A Life Worth Ending” (2012) 28 May New York Magazine.

${ }^{67}$ John Bayley Iris (Abacus, London, 2002) at 261-262.

${ }^{68}$ At 276.
} 
In fact, her whole character seems to have changed. Bayley recounts Murdoch's former love of complex, philosophical discussions on literature, before noting that they no longer make sense to her. Instead, she watches Teletubbies on television: ${ }^{69}$

Iris likes it, and it has a soothing effect, making her sit watching TV for longer periods. Otherwise she is apt to get up and stand with her back to the TV, fiddling incessantly with her small objets trouvés - twigs and pebbles, bits of dirt, scraps of silver foil, even dead worms rescued from the pavement on our short walks.

It seems unlikely that Murdoch would "have thought any of this hoarding and turmoil was hers. None of it comes from any conscious self-creation...It came from atrophy of the brain." 70

To return to the argument. Under the Psychological Approach, for $\mathrm{X}$ to be the same person as the agent of $\varphi, X$ must be psychologically continuous with the agent of $\varphi$. Given the clinical indicators, symptoms, and experiences of Alzheimer's-dementia, it seems more than plausible that person-at-70 is no longer psychologically continuous with person-at-25 - the agent of $\varphi$. If so, person-at-70 is not the same person as person-at- 25 . Returning to my third assumption in part II - that for someone now to be criminally responsible for some past action $\varphi$, this person must be the same person as the agent of $\varphi$ - this means that person-at-70 cannot be criminally responsible for person-at-25's crime.

\section{Objections}

One might have some concerns about the consequences of this argument. I will deal with three such concerns. In sections A and B, I will discuss two objections which attack the scope of my argument. Sceptics might worry that application of the Psychological Approach would allow blameworthy people - including war criminals - to go unpunished. I will respond that this concern is unfounded. In section C, I will discuss another problem: that victims of such crimes may feel that justice has not been done. I will explore other ways of managing this issue.

\footnotetext{
${ }^{69}$ At 242.

${ }^{70}$ Glover, above n 64, at 372.
} 


\section{F Avoidance of Liability}

First, imagine a variation of the opening scenario:

Suppose a person - Ben - commits a crime at 25 years old. Ben quickly tries to hide the evidence of his crime. He knows that he has inherited Huntington's disease, which leads to dementia. ${ }^{71}$ He expects symptoms to appear at around age 35, and he does everything he can to hasten progression of the disease - he thinks that, once the psychological effects are present, he won't be the same person who committed the crime and so he won't be punished.

On the Psychological Approach described above, it seems that a future person may eventually lack sufficient psychological connections with Ben, in which case they will not be liable for the crime. One might object to the PA on the basis that this person, who has tried to avoid liability, seems more culpable than average, not less. One might also worry that allowing an avenue to avoid liability could encourage more offending.

We might think that the Biological Approach better captures our intuitions in this scenario. As Ben and the future person with dementia are biologically continuous, they will be the same person. The future person will be the owner of the actions.

However, the Biological Approach is susceptible to a similar objection.

Suppose Paul commits a crime at 25 years old. He quickly tries to hide the evidence of his crime. He plans to commit suicide the following day - he thinks that, once he is dead, he cannot be punished.

On some versions of the BA, death ends biological continuity. If so, Paul's existence comes to an end when he commits suicide. This means, even though Paul, too, seems more liable, we cannot punish him once he is dead. On other views, biological continuity persists as long as the body does - whether or not it is alive. This has the implausible result that Paul's corpse is the owner of the crime.

\footnotetext{
71 Huntington's disease is a progressive, incurable, hereditary brain disorder. Symptoms usually begin between the ages of 30 and 50, but can appear earlier. The most obvious symptoms of Huntington's are involuntary movements, but it also has severe effects on mood and behaviour and commonly leads to dementia. Alzheimer's Association “Huntington's Disease” <http:/www.alz.org/dementia/huntingtonsdisease-symptoms.asp>; Julie Snowden "Behavioural Problems in Huntington's Disease" [1996] 50 Huntington's disease Association: London.
} 


\section{Culpability}

People who plan to evade liability, by whatever means, seem to be more culpable than those who do not. ${ }^{72}$ However, this is not an objection to the Psychological Approach. As the case with Paul shows - people find ways to avoid liability no matter what view of identity we endorse. The fact is, it is Ben that seems more culpable. It is nonetheless true that, once the future person has developed dementia - and is no longer psychologically continuous with Ben, who committed the crime - they are not culpable. We must be careful to avoid conflating Ben with the person with AD. No matter what we think about Ben's culpability, the person with AD is not him. They, like Paul's dead body, no longer stand in the right kind of relationship to the crime.

\section{Encourage Offending}

One might also submit that Ben's behaviour could encourage offending by others. However, this would only be true if others thought that Ben was 'getting away with' his crime. In a sense that is true, as Ben, if successful, is never punished for his crime. However, it must be remembered that the person with $\mathrm{AD}$ is another person; the person who committed the crime is gone. Someone like Ben would have to be willing to give up their own identity in order to avoid punishment. Their action, although less immediate, would be essentially the same as Paul's.

It seems unlikely that many people would be willing to lose their identity to avoid liability. However, if they did, we could not justifying punishing the future people with $\mathrm{AD}$ on the basis of desert. Other grounds of punishment, such as deterrence, may justify punishment. However, these are beyond the scope of this paper.

\section{G War Crimes}

Some might object to my argument on the following basis: Some people who have committed atrocious war crimes, for example during World War II, now have advanced dementia. If my argument succeeds, those people will not be liable for their crimes. It is

\footnotetext{
${ }^{72}$ Such an attempt may be evidence of lack of remorse, for example.
} 
absurd that a person who committed atrocious war crimes will not be liable, therefore my argument is false.

However, a person who advances such an argument is misunderstanding my claim. I agree that it would be absurd for a person who committed such heinous crimes not to be held liable. But remember, my argument is that a person with AD is sometimes no longer the same person who committed the crime. It does not follow from this, as is presumed in the above objection, that 'a person who committed atrocious war crimes will not be liable.' My claim entails that some people who committed atrocious war crimes no longer exist. I am only saying that a person with $\mathrm{AD}$ is not culpable if and because they are not the same person as the one who committed the crime.

Consider Johann Breyer. ${ }^{73}$ He was born in 1925 in Czechoslovakia and enlisted in the Waffen-SS, a military unit of the Schutzstaffel, in 1942. He served briefly as a guard at Auschwitz. In 1952, he moved to the United States and gained citizenship five years later. In 2013, when Breyer was 89, he was arrested on 158 counts of accessory to murder. Breyer suffered from dementia and heart conditions, and died before an extradition hearing could be held.

Due to his dementia, Breyer-in-2013 was no longer psychologically continuous with Breyer-in-1942. Thus on the Psychological Approach, Breyer-in-2013 and Breyer-in1942 were not the same person. Assuming Breyer voluntarily committed the crimes ${ }^{74} \mathrm{I}$ agree that he was liable in 1942. He deserved punishment for his acts. However, Breyerin-2013 did not deserve punishment; he was not the same person as the one who committed the crime.

\footnotetext{
${ }_{73}$ Terrence McCoy “Johann Breyer, 89, charged with 'complicity in murder' in US of 216,000 Jews at Auschwitz" The Sydney Morning Herald (20 June 2014) <www.smh.com.au>; "Nazi war crimes suspect dies as US approves extradition to Germany" (23 July 2014) Al Jazeera America <america.aljazeera.com>. ${ }^{74}$ And ignoring other issues - such as the fact that he was a minor when he enlisted and claimed to never witness or be part of any deaths.
} 
Once this fact is understood, it no longer seems absurd not to hold such people with AD liable. This means we could not punish them on the basis of desert.

This approach in no way endorses or condones the war crimes. Instead, it recognises the fact that, if we care about desert, we ought not to punish another innocent person.

\section{H Effect on Victims}

The Psychological Approach does nothing to address the needs or rights of victims of historical offending. If my argument succeeds, some people that might otherwise have been convicted of a crime will not be. Victims may feel that justice has not been done, or that they will be disadvantaged due to the lack of a conviction.

We ought not to punish non-deserving people, like the person with $\mathrm{AD}$, in order to satisfy these aims. However, there may be other ways to address the harm done.

\section{Injustice}

The first issue is that, without a conviction, victims may feel that justice has not been done. This relates back to our theory of punishment, just deserts. Although retribution is offender-oriented, it affects victims.

In a retributivist account, punishment is necessarily connected to guilt. Both positive and negative accounts of retributivism agree that the innocent must not be punished, and the guilty must not be punished more than they deserve. Therefore, the punishment is in itself a symbol of guilt. For a victim, it may serve as an acknowledgement that the crime was committed and that the offender was accountable. Retribution also has a denunciation element. The crime is publicly condemned by society. Through denunciation, the victim may feel that the harm they suffered has been recognised.

Let us return to the opening scenario, and imagine the crime was committed against a victim. If my argument about persistence of identity succeeds, the person-at-70 will not 
be culpable for the crime, and will not be convicted or punished. The victim may feel that neither the offence nor their suffering has been adequately acknowledged.

The solution cannot be to punish the person with AD. It cannot be justified by our theory of punishment. The person-at-70 has not committed an offence; they are not the same person as the one who committed the crime at 25. Punishing the person-at-70 would not serve as an acknowledgement that the crime was committed or that the person-at-25 was culpable. It would be meaningless, and no more apt than punishing any person picked off the street. The victim does not want just anyone punished; they want the culpable person punished. If the victim understands the truth of the matter - that the person who offended against them is gone, that the person now present is no longer psychologically continuous with the person who committed the crime - it is doubtful that they will find punishing that person brings them much comfort.

However, there may be other ways to remedy this. ${ }^{75}$ We do not need a conviction to acknowledge the wrong or the suffering. Perhaps, for example, the court or government could issue a formal apology to the victim. ${ }^{76}$ It may not be possible to declare that the offence occurred; it would not be fair to the defendant without a trial. However, they could make a public statement recognising that the victim was harmed and apologise that justice was not done.

\footnotetext{
75 Neither mediation nor restorative justice would be appropriate. Both involve the offender's acknowledgement of wrongdoing. The person-at-70 did not commit the offence.

76 One may think that the person-at-70 could apologise to the victim. However, they may be no more connected to the person who committed the crime than you or I. Such an apology would not be especially meaningful; it would be akin to an apology from the family member of a defendant. The court or government would have standing to apologise, as they would have the same identity as they had at the time the offence occurred.
} 


\section{Disadvantage to Victims}

Section 7(1) of the Sentencing Act 2002 states the purposes for which a court may sentence an offender. The following purposes may have consequences for the victim of the offence: ${ }^{77}$

(a) to hold the offender accountable for harm done to the victim and the community by the offending; or

(b) to promote in the offender a sense of responsibility for, and an acknowledgement of, that harm; or

(c) to provide for the interests of the victim of the offence; or

(d) to provide reparation for harm done by the offending;

Without a conviction, this statute will not come into consideration. One might object that victims will be disadvantaged because of this.

This is not necessarily the case. It may be possible to provide for the interests of the victim. Paragraph (c) stems from restorative justice, which is about rectifying the wrong done to the victim. Typically, the restoration comes from the offender. However, there are other means of providing for the victim which do not rely on the offender.

The government has recognised that victims needs should be met regardless of whether there has been a conviction. The Victims' Rights Act 2002 defines 'offence' to include "an alleged offence (whether or not a person is convicted of the offence)." 78 Section 9 of this Act says:

A victim or member of a victim's family who has welfare, health, counselling, medical, or legal needs arising from the offence should have access to services that are responsive to those needs.

This section does not guarantee enforceable rights, ${ }^{79}$ but indicates that victims can expect help and support.

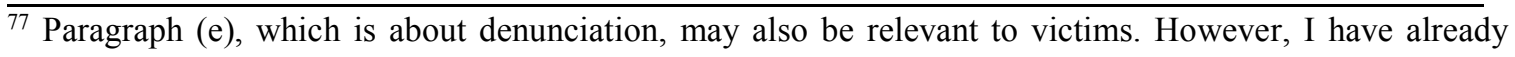
discussed other ways of denouncing conduct.

78 Victims' Rights Act 2002 s 4, definition of “offence”, para (b).

${ }^{79}$ But note that the rights are not guaranteed even where there has been a conviction. See Victims' Rights Act 2002, s 10 .
} 
Agencies and services can provide for the emotional and psychological needs of the victim by offering free or subsidised counselling. ${ }^{80}$ For victims of sexual offending, there are centres which offer services (such as 24-hour support, free specialised counselling, information and advocacy) regardless of how long ago the crime occurred or whether it was reported. ${ }^{81}$ Victims may also be eligible for financial assistance from Victim Support.

Paragraphs (a), (b) and (d) are focused on the offender. Unfortunately, we cannot fulfil these purposes without an offender. It is regrettable for victims that accountability, responsibility and reparation are dependent on a conviction and sentence. However, the person-at-70 is simply not accountable or responsible for the harm or offending, and thus not liable to provide reparation. It is impossible to promote an acknowledgement of harm in a person who no longer exists. Hopefully there are other ways for the victim to get closure. Punishing the person-at-70, who is not the same person as the one who committed the crime, is not the answer.

\section{Further Application}

If we accept the Psychological Approach, development of dementia will not be the only occasion in which persistence of personal identity is disrupted.

This paper was limited to historic offending and focused on the dementia of the Alzheimer's type. This was, in part, because these factors allowed us to assume that significant time had passed between the original offending and the onset of dementia symptoms. Consequently, the argument could be extended to other cases of historical offending where the defendant does not have dementia, so long as they no longer have strong chains of psychological connectedness with the person who committed the offence.

\footnotetext{
${ }^{80}$ From ACC or START www.starthealing.org.

81 For example, Wellington Rape Crisis (www.wellingtonrapecrisis.org.nz) or Sexual Abuse Help Foundation (www.wellingtonhelp.org.nz).
} 
Recall that, on the Psychological Approach, $\mathrm{X}$ at $\mathrm{t}_{1}$ is the same individual as $\mathrm{Y}$ at some other time if and only if $\mathrm{Y}$ is uniquely psychologically continuous with $\mathrm{X}$. I argued that the psychological effects of dementia may undermine this continuity. It seems plausible that someone without dementia might also lack psychological continuity with a former person who committed a crime. It may be rarer than in people with $\mathrm{AD}$, but it is possible that the passage of 60 years or so could disrupt psychological continuity to sufficient degree that a person would not deserve punishment.

An example might look similar to the case of $R v$ Samuel. ${ }^{82}$ Samuel committed one rape and one indecent assault on young girls when he was approximately 20 years old. He then married, had children and never offended again. Samuel was sentenced at 65 years old. The judge, Priestly J, was satisfied that he had since "led a blameless and exemplary life." ${ }^{83} \mathrm{He}$ had an excellent work record, and was the senior elder of his church where he had "obviously positively affected the lives of many people". ${ }^{84}$ Although Samuel did not suffer from dementia, it was accepted that he truly could not remember the details of his offending. Priestly J was confident that Samuel was "not a sexual predator at this stage of [his] life nor a risk to the public". ${ }^{85}$

Given these facts, it seems entirely possible that Samuel now is not strongly psychologically connected with the person who committed the rape and assault.

This significantly widens the scope of my argument. However, it does not mean that all historical offences would go unpunished. Only adequate psychological changes would negate culpability. With Alzheimer's, there are diagnostic criteria and physiological indicators that we can use to show psychological discontinuity. If we expand the argument to those without dementia, we would need to develop reliable ways of

\footnotetext{
82 [2013] NZHC 689.

${ }^{83}$ At [7].

${ }^{84}$ At [7].

${ }^{85}$ At [10].
} 
identifying sufficient psychological changes. As much research is still to be done on diagnosing Alzheimer's earlier, this is unlikely to occur in the near future. Even so, we ought to keep in mind that in some cases, the person on trial may not be the same person as the one who committed the crime, and ought not to be convicted or punished.

\section{$X$ Conclusion}

I have argued that, on a plausible theory of personal identity, dementia may well undermine desert for punishment. I began by laying out features of dementia and just deserts. I considered two common approaches to personal identity and showed why one approach is preferable. Assuming this theory is correct, I argued that dementia is likely to undercut psychological connectedness and hence personal identity. This undermines criminal responsibility and thus desert for offending. To finish, I noted three objections and argued that they were not convincing. Finally, there are further applications to this argument. Although dementia is not a normal part of ageing but a progressive disease, the psychological changes may be present to a lesser degree in older people without dementia. If so, and if psychological continuity is the correct theory, questions are raised about the legitimacy of punishing historical offending for people without dementia. 


\section{BIBLIOGRAPHY}

\section{A Cases}

$R v$ Hart CA199/93, 17 November 1993.

$R v$ TA HC Auckland T296/96, 12 December 1996.

$R v$ Shoebridge HC Hamilton T014189, 12 September 2002.

Civil Aviation Department v MacKenzie [1983] NZLR 78.

Millar v Ministry of Transport [1986] 1 NZLR 660.

B (A Minor) v Director of Public Prosecutions [2000] 2 WLR 452 (HL).

$R v$ Milligan [2013] NZHC 118.

\section{B Legislation}

Victims' Rights Act 2002.

\section{Books and Book Chapters}

American Psychiatric Association Diagnostic and statistical manual of mental disorders (4th text revision ed, American Psychiatric Association, Washington, DC, 2000).

American Psychiatric Association Diagnostic and statistical manual of mental disorders (5th ed, American Psychiatric Association, Washington, D.C, 2013).

Bayley, John Iris (Abacus, London, 2002).

Butler, Joseph "Of Personal Identity" in John Perry (ed) Personal Identity (University of California Press, Berkeley, 1975).

DeGrazia, David Human Identity and Bioethics (Cambridge University Press, Cambridge, 2005).

Duff, Antony Trials and Punishments (Cambridge University Press, Cambridge; New York, 1986).

Dworkin, Ronald Life's Dominion: An argument about abortion, euthanasia, and individual freedom (Knopf Doubleday, New York, 1994).

Ferzan, Kimberly Kessler "Justification and Excuse" in John Deigh and David Dolinko (eds) The Oxford Handbook of the Philosophy of the Criminal Law (Oxford University Press, 2011).

Fletcher, George Rethinking Criminal Law (Little, Brown and Company, Boston, 1978). 
Glover, Jonathan Alien Landscapes?: Interpreting Disordered Minds (Harvard University Press, Cambridge, Massachusetts, 2014).

Hart, HLA The Concept of Law (Third edition ed, Oxford University Press, Oxford, United Kingdom, 2012).

Husak, Douglas N Philosophy of Criminal Law (Rowman \& Littlefield, Totowa, 1987).

Inwagen, Peter Van Material beings (Cornell University Press, Ithaca, N.Y, 1990).

Lewis, David K "Survival and Identity" in Raymond Martin and John Barresi (eds) Personal Identity (Blackwell Publishing, Malden, 2003).

Locke, John "Of Identity and Diversity" in John Perry (ed) Personal identity (University of California Press, Berkeley, 1975) 33.

McMahan, Jeff The Ethics of Killing (Oxford University Press, 2002).

Nagel, Thomas "Brain Bisection and the Unity of Consciousness" in John Perry (ed) Personal identity (University of California Press, Berkeley, 1975).

Nozick, Robert Philosophical Explanations (Clarendon Press, Oxford, 1981).

Olson, Eric T The Human Animal: Personal Identity Without Psychology (Oxford University Press, New York, 1997).

Olson, Eric T "Personal Identity" in Edward N Zalta (ed) The Stanford Encyclopedia of Philosophy (Winter 2010 ed, 2010).

Parfit, Derek "Personal Identity" in John Perry (ed) Personal Identity (University of California Press, Berkeley, 1975).

Parfit, Derek Reasons and Persons (Clarendon Press, Oxford, 1984).

Reid, Thomas "Of Mr Locke's Account of Our Personal Identity" in John Perry (ed) Personal identity (University of California Press, Berkeley, 1975) 113.

Robinson, Paul Criminal Law Defenses (West Publishing, St Paul, 1984).

Shoemaker, David "Personal Identity and Ethics" in Edward N Zalta (ed) Stanford Encyclopedia of Philosophy (Spring 2014 ed, 2014).

Williams, Bernard "The Self and the Future" in John Perry (ed) Personal Identity (University of California Press, Berkeley, 1975).

World Health Organization and Alzheimer's Disease International Dementia: A Public Health Priority (World Health Organization; Alzheimer's Disease International, Geneva; London, 2012). 


\section{Journal Articles}

Austin, JL “A Plea for Excuses” (1956) 57 Proceedings of the Aristotlean Society 1.

Benbow, Susan M and Kingston, Paul "Talking about my experiences ... at times disturbing yet positive': Producing narratives with people living with dementia" [2014] Dementia 1.

Buchanan, Allen “Advance Directives and the Personal Identity Problem" (1988) 17 Philosophy \& Public Affairs 277.

Carter, William R "How to Change Your Mind" (1989) 19 Canadian Journal of Philosophy 1.

Dresser, Rebecca "Dworkin on dementia: Elegant theory, questionable policy" (1995) 25 The Hastings Center Report 32.

Gardner, John "The Mark of Responsibility” (2003) 23 Oxford Journal of Legal Studies 157.

Gevers, Sjef "Dementia and the Law" (2006) 13 Eur J Health L 209.

Glannon, Walter "Moral Responsibility and Personal Identity" (1998) 35 American Philosophical Quarterly 231.

Hall, Jerome "Comment on Justification and Excuse" (1976) 24 American Journal of Comparative Law 638.

Harvey, Martin "Advance Directives and the Severely Demented" (2006) 31 Journal of Medicine and Philosophy 47.

Husak, Douglas "On the Supposed Priority of Justification to Excuse" [2005] 24 Law and Philosophy 557.

Landau, Susan and others, Alzheimer's Disease Neuroimaging Initiative "Associations between cognitive, functional, and FDG-PET measures of decline in AD and MCI" (2011) 32 Neurobiology of Aging 1207.

Lewis, Penney "Medical Treatment of Dementia Patients at the End of Life: Can the Law Accommodate the Personal Identity and Welfare Problems?" (2006) 13 European Journal of Health Law 219.

Mackie, David "Personal Identity and Dead People" (1999) 95 Philosophical Studies 219.

Perry, John "Can the Self Divide?" (1972) 69 The Journal of Philosophy 463.

Shoemaker, David "Responsibility without identity" (2012) 185 Science 1124.

Smart, Alwynne "Mercy" (1968) 43 Philosophy 345. 
Snowden, Julie “Behavioural Problems in Huntington's Disease” [1996] 50 Huntington's Disease Association: London.

Stern, K “Advance Directives” (1994) 2 Medical Law Review 57.

Various authors "Symposium: Joint Conference on Legal/Ethical Issues in the Progression of Dementia" (2001) 35 Georgia Law Review 451.

\section{E Reports}

Alzheimer's Disease International World Alzheimer Report 2009 (2009).

Alzheimer's Disease International World Alzheimer Report 2011 (Alzheimer's Disease International, London, 2011).

Deloitte Access Economics Updated Dementia Economic Impact Report, 2011, New Zealand (2012).

National Institute on Aging Alzheimer's Disease: Unraveling the Mystery (08-3782, 2008).

Alzheimer's Association “Alzheimer's Disease and the Brain: Under the microscope" (2011) Alzheimer's Association <www.alz.org $>$.

\section{G Internet Materials}

Alzheimer's Association "7 Stages of Alzheimer's \& Symptoms" Alzheimer's Association $<$ www.alz.org $>$.

Alzheimer's Association "Huntington's Disease" $<$ http://www.alz.org/dementia/huntingtons-disease-symptoms.asp>.

Alzheimers New Zealand "Progression of dementia" Alzheimers New Zealand $<$ www.alzheimers.org.nz>.

Bascand (Government Statistician), Geoff "National Population Projections: 2011(base)2061” (19 July 2012) Statistics New Zealand <www.stats.govt.nz>.

Statistics New Zealand "Projected population of New Zealand by age and sex, 2011(base)-2061”(22 October 2013) NZ.Stat <nzdotstat.stats.govt.nz>.

\section{F Other Sources}

"Nazi war crimes suspect dies as US approves extradition to Germany" (23 July 2014) Al Jazeera America <america.aljazeera.com>.

McCoy, Terrence "Johann Breyer, 89, charged with 'complicity in murder' in US of 216,000 Jews at Auschwitz" The Sydney Morning Herald (20 June 2014) $<$ www.smh.com.au>. 
Wolff, Michael “A Life Worth Ending” (2012) 28 May New York Magazine. 